\title{
Systematic Review \\ The Comparative Effects of Different Types of Oral Vitamin Supplements on Arterial Stiffness: A Network Meta-Analysis
}

\author{
Alicia Saz-Lara ${ }^{1}$, Iván Cavero-Redondo ${ }^{1, *(\mathbb{D})}$, Vicente Martínez-Vizcaíno ${ }^{1,2}{ }^{(0)}$, Isabel Antonia Martínez-Ortega ${ }^{1}$, \\ Blanca Notario-Pacheco ${ }^{1}$ and Carlos Pascual-Morena ${ }^{1}$ (D) \\ 1 Health and Social Research Center, Universidad de Castilla-La Mancha, 16171 Cuenca, Spain; \\ alicia.delsaz@uclm.es (A.S.-L.); vicente.martinez@uclm.es (V.M.-V.); isabela.martinez@uclm.es (I.A.M.-O.); \\ blanca.notario@uclm.es (B.N.-P.); carlos.pascual@uclm.es (C.P.-M.) \\ 2 Facultad de Ciencias de la Salud, Universidad Autónoma de Chile, Talca 3460000, Chile \\ * Correspondence: ivan.cavero@uclm.es
}

Citation: Saz-Lara, A.;

Cavero-Redondo, I.;

Martínez-Vizcaíno, V.;

Martínez-Ortega, I.A.;

Notario-Pacheco, B.; Pascual-Morena,

C. The Comparative Effects of

Different Types of Oral Vitamin

Supplements on Arterial Stiffness: A

Network Meta-Analysis. Nutrients

2022, 14, 1009. https://doi.org/

10.3390/nu14051009

Academic Editor: Rosa Casas

Received: 7 February 2022

Accepted: 25 February 2022

Published: 27 February 2022

Publisher's Note: MDPI stays neutral with regard to jurisdictional claims in published maps and institutional affiliations.

Copyright: (c) 2022 by the authors. Licensee MDPI, Basel, Switzerland. This article is an open access article distributed under the terms and conditions of the Creative Commons Attribution (CC BY) license (https:// creativecommons.org/licenses/by/ $4.0 /)$.

\begin{abstract}
Arterial stiffness, a significant prognostic factor of cardiovascular disease, may be affected by dietary factors. Research on the effects of oral vitamin supplements on arterial stiffness and/or endothelial function has produced controversial results. Therefore, the aim of this network metaanalysis was to comparatively assess the effect of different types of oral vitamin supplements on arterial stiffness in the adult population. We searched the PubMed, Embase, Cochrane Library, and Web of Science databases for randomized controlled trials from their inception to 30 September 2021. A network meta-analysis using a frequentist perspective was conducted to assess the effects of different types of oral vitamin supplements on arterial stiffness, as determined by pulse wave velocity. In total, 22 studies were included, with a total of 1318 participants in the intervention group and 1115 participants in the placebo group. The included studies were listed in an ad hoc table describing direct and indirect comparisons of the different types of vitamins. Our findings showed that, in both pairwise comparison and frequentist network meta-analysis, the different types of oral vitamin supplements did not show statistically significant effects on arterial stiffness. However, when oral vitamin supplementation was longer than 12 weeks, vitamin D3 showed a significant reduction in arterial stiffness, compared with the placebo (ES: $-0.15 ; 95 \% \mathrm{CI}:-0.30,-0.00 ;-60.0 \% \mathrm{~m} / \mathrm{s}$ ) and vitamin D2 (ES: $-0.25 ; 95 \%$ CI: $-0.48,-0.02,-52.0 \% \mathrm{~m} / \mathrm{s})$. In summary, our study confirms that oral vitamin D3 supplementation for more than 12 weeks could be an effective approach to reduce arterial stiffness and could be considered a useful approach to improve vascular health in patients at high risk of cardiovascular disease.
\end{abstract}

Keywords: arterial stiffness; pulse wave velocity; oral vitamin supplementation; adults; network meta-analysis

\section{Introduction}

Arterial stiffness is related to the onset of vascular aging [1] and could be considered a contributing factor for the development of cardiovascular disease (CVD) [2]. Inflammation and oxidative stress are possible mechanisms of arterial stiffness. Both mechanisms are able to induce changes in the endothelium and arterial wall structure through processes such as smooth muscle cell proliferation, collagen deposition, and elastin fragmentation [3]. Using disease risk stratification strategies to prevent the alteration of the vascular function and structure during the preclinical phases of disease may have different health benefits [4,5]. Pulse wave velocity (PWv) measurement is the gold standard method for the noninvasive assessment of arterial stiffness [2,6]. PWv is a useful surface indicator for determining cardiovascular risk $[2,7,8]$ and targeting potential organ damage. However, the effects of reducing arterial stiffness, as measured by PWv, over time have yet to be determined [5].

Arterial "de-stiffening" is a topic of particular interest in preventing CVD. Currently, socioeconomic improvement and nutritional changes observed in the general population 
are associated with an increase in the prevalence of cardiometabolic diseases [9], with global trends of nutritional insufficiency [10]. Since diets are modifiable, their different components may increase or decrease the progression of CVD. Previous studies have shown that diets such as the Mediterranean diet that are rich in antioxidants and nutrients with anti-inflammatory properties can improve vascular function [11-14]. Furthermore, vitamin supplements are commonly used in Western countries, and observations show that, while vitamin supplements may provide health benefits, the potential health risks must also be considered [15].

Although there are several previously published systematic reviews and metaanalyses [16-23] on the effects of different types of oral vitamin supplements on arterial stiffness and/or endothelial function, and although the number of samples included in the assessment of some types of oral vitamin supplements is limited (and not all types of vitamins have been tested for arterial stiffness), none of them has quantitatively assessed the effects of different types of oral vitamin supplementation (folic acid or vitamin B9, ascorbic acid or vitamin C, calcitriol or vitamin D, ergocalciferol or vitamin D2, cholecalciferol or vitamin D3, tocotrienol or vitamin E) on arterial stiffness. Therefore, the aim of this network meta-analysis (NMA) was to assess the effects of different types of oral vitamin supplements on the reduction in arterial stiffness.

\section{Materials and Methods}

This NMA was reported in compliance with the preferred reporting items for systematic review incorporating NMA (PRISMA-NMA) guidelines [24] and the Cochrane Collaboration Handbook [25]. This study was registered in PROSPERO (Registration Number: CRD42021253233). This study included data from previously published studies, so it did not include individual patients and no prior ethical approval was required.

\subsection{Search Strategy}

Two reviewers (A.S.-L. and I.C.-R.) independently conducted systematic searches of the PubMed, Web of Science, Cochrane Library, and Scopus databases from their inception to 30 September 2021. Free terms in combination with Boolean operators were used to perform the search, following the PICO strategy (population, intervention/exposure, comparison, and outcome): "adults", "young adults", "older adults", "elderly adults", " adult population", "adult subjects", "vitamins", "oral vitamin supplementation", "vitamin B9", "folic acid", "vitamin C", " ascorbic acid", "vitamin D", "calciferol”, "vitamin D3", , cholecalciferol", "vitamin D2", "ergocalciferol", "vitamin E", “tocopherol", "arterial stiffness", "aortic stiffness", "pulse wave velocity", and "PWv". Table S1 shows the search strategy. In addition, to achieve a more comprehensive search, references of included articles, and previous systematic reviews or meta-analyses in the field were reviewed.

\subsection{Eligibility}

Studies concerning the effects of oral vitamin supplements on arterial stiffness were included in the NMA. Studies were selected based on the following inclusion and exclusion criteria. Inclusion criteria: (1) studies: RCTs; (2) population: subjects older than 18 years old; (3) intervention: oral vitamin supplements (folic acid or vitamin B9, ascorbic acid or vitamin $C$, calcitriol or vitamin D, ergocalciferol or vitamin D2, cholecalciferol or vitamin D3, tocotrienol or vitamin E) with a duration of at least 4 weeks; (4) outcome: arterial stiffness measured by PWv. Exclusion criteria: (1) single-arm pre- and post-studies; (2) studies combining oral vitamin supplementation with pharmacological treatments; and (3) studies in which the type and dose of vitamins could not be estimated.

\subsection{Study Selection and Data Extraction}

Study selection and data extraction were performed independently by two researchers (A.S.-L. and I.C.-R.). The following information was extracted from the included studies: (1) reference (first author and year of publication); (2) country in which the study data 
were collected; (3) population characteristics (sample size (\%female), mean age, type of population (healthy or with a specific disease)); (4) intervention characteristics (type of vitamins (folic acid or vitamin B9, ascorbic acid or vitamin $C$, calcitriol or vitamin $D$, ergocalciferol or vitamin D2, cholecalciferol or vitamin D3, tocotrienol or vitamin E), oral supplementation dose (frequency), length); (5) outcome: arterial stiffness measured by PWv (type of PWv (aortic PWv (a-PWv), brachial-to-ankle PWv (ba-PWv), brachial-to-radial PWv (br-PWv), carotid-to-femoral PWv (cf.-PWv), carotid-to-radial PWv (cr-PWv)), PWv device, baseline PWv levels, percentage of change) (Table 1).

\subsection{Risk of Bias Assessment}

Two researchers (A.S.-L. and I.C.-R.) independently performed an assessment of the methodological quality of the included RCTs using the Cochrane Collaboration tool for assessing the risk of bias (RoB2) [26] following the Cochrane manual for the systematic review of interventions [25] with information on authors, dates, and sources of each included manuscript blinded. This tool assesses the risk of bias based on six domains: selection bias, performance bias, detection bias, attrition bias, reporting bias, and other biases. Overall bias was rated "low risk of bias" when all domains were classified as "low risk", "some concerns" when there was at least one domain classified as "some concern", and "high risk of bias" when there was at least one domain classified as "high risk" or several domains classified as "some concerns". Disagreements were handled by consensus or by a third reviewer (C.P.-M.).

\subsection{Grading the Quality of Evidence}

We used the Grading of Recommendations, Assessment, development, and Evaluation (GRADE) tool [27] to assess the quality of evidence and provide recommendations. Each outcome had a high, moderate, low, or very low evidence score, depending on study design, risk of bias, inconsistency, indirect evidence, imprecision, and publication bias.

\subsection{Data Synthesis and Statistical Analysis}

The included studies were qualitatively reported in an ad hoc table depicting direct and indirect comparisons of different types of oral vitamin supplements. Our NMA was conducted in accordance with the PRISMA-NMA statement [24] under a frequentist perspective by following these steps:

- $\quad$ First, we used a network geometry graph to depict the trials in the network. In this graph, the size of the nodes was relative to the number of participants in trials receiving the intervention identified in the node, and the width of the solid line connecting the nodes was relative to the number of participants in trials directly comparing the two interventions. Dashed lines depict indirect comparisons between two interventions [28].

- $\quad$ Second, the consistency assessment tested whether the intervention effect calculated from direct comparisons was robust with those calculated by indirect comparisons. For this purpose, we used the Wald test, and we evaluated local inconsistency using the side-splitting method.

- Third, we performed a comparative assessment of the intervention effect by performing a standard pairwise meta-analysis for comparisons between interventions and placebo/other interventions. For this purpose, we used the DerSimonian-Laird random-effects method [29] to calculate a pooled effect size (ES) estimate and the respective $95 \%$ confidence intervals (CIs), and we estimated the pooled percentage change in $\mathrm{m} / \mathrm{s}$ for oral vitamin supplement interventions. We examined statistical heterogeneity by calculating the I2 statistic, ranging from $0 \%$ to $100 \%$. Depending on the I2values, heterogeneity was classified as unimportant $(0 \%$ to $30 \%)$, moderate $(30 \%$ to $50 \%$ ), substantial (50\% to $75 \%$ ), or considerable $(75 \%$ to $100 \%)$ [25]. In addition, we considered the corresponding $\mathrm{p}$ values. Finally, we calculated the statistic $\tau 2$ to establish the size and clinical relevance of heterogeneity. A $\tau 2$ estimate of 0.04 can be 
considered as low, 0.14 as moderate, and 0.40 as a substantial degree of the clinical relevance of heterogeneity [30]. We created both forest plots and a league table to depict these results.

- $\quad$ Fourth, we calculated the effect of each intervention using NMA with a frequentist perspective [31]. Frequentist perspective draws a conclusion based on the level of statistical significance and the acceptance or rejection of a hypothesis.

- $\quad$ Fifth, we used sensitivity, subgroup, and meta-regression analyses for the transitivity evaluation, and we verified that all study participants included in the NMA had, on average, a similar baseline effect distribution. We conducted a sensitivity analysis (systematic reanalysis while eliminating studies one at a time) to evaluate the strength of the summary estimates. We used subgroup analyses based on the mean population age $(<65$ years or $>65$ years), intervention length $(<12$ weeks or $>12$ weeks), vitamin type (water-soluble (vitamin B9 and vitamin C) or fat-soluble (vitamin D, vitamin D2, vitamin D3, and vitamin E)), and PWv type (central PWv (a-PWv and cf.-PWv) or peripheral PWv (ba-PWv, br-PWv, and cr-PWv)). We performed meta-regression analyses to address whether the mean age and intervention length, as continuous variables, modified the effect of oral vitamin supplementation interventions on PWv.

- Sixth, once the effect size estimates of the efficacy of oral vitamin supplementation interventions were calculated, we ranked and plotted the interventions using rankograms [32]. In addition, we calculated the surface under the cumulative ranking (SUCRA) [28] for each intervention.

- Finally, publication bias was assessed through visual inspection of the funnel plots, and Egger's test [33].

We performed all analyses using Stata 15.0 (Stata, College Station, TX, USA). 
Table 1. Characteristics of the included studies.

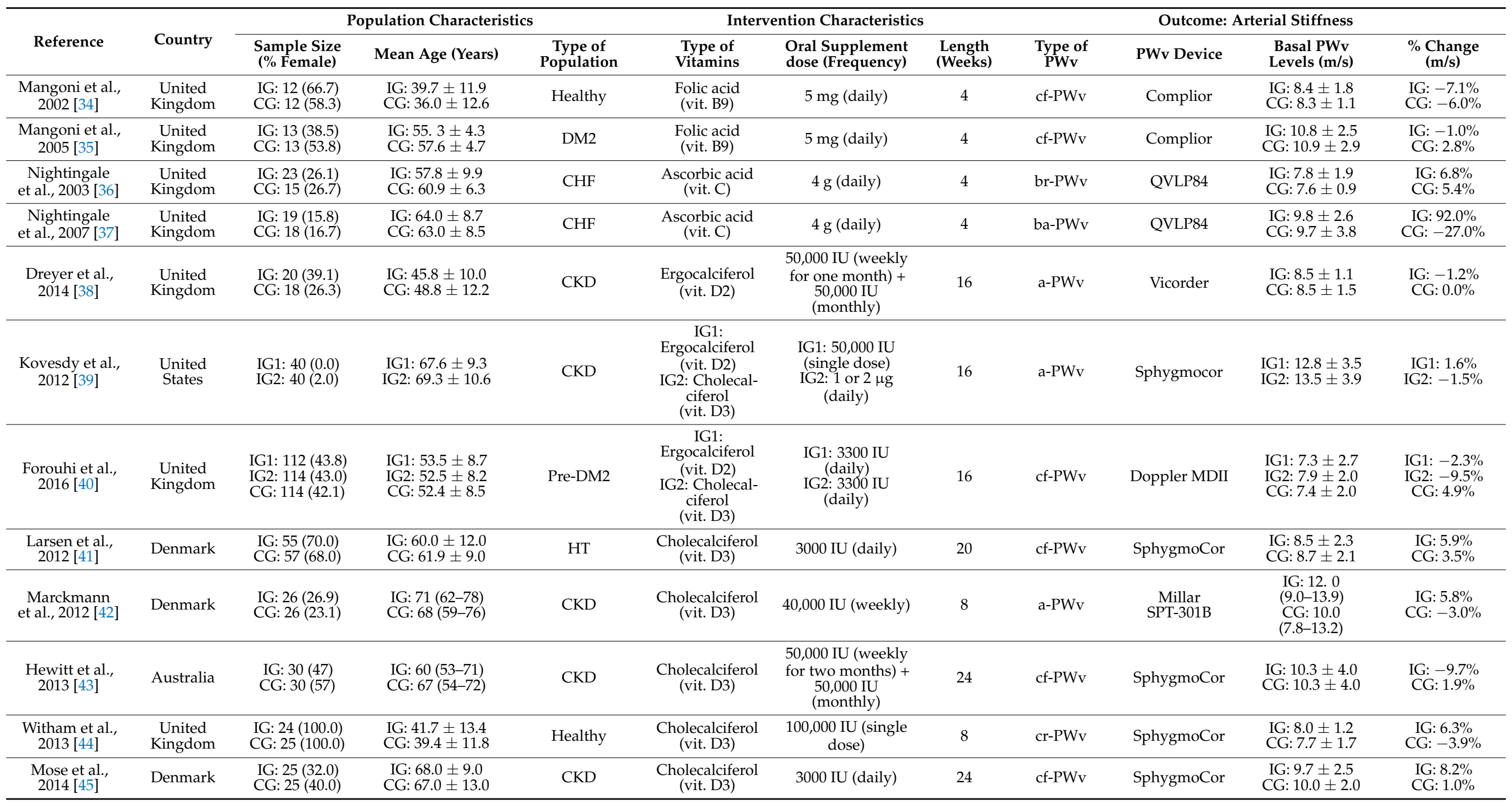


Table 1. Cont.

\begin{tabular}{|c|c|c|c|c|c|c|c|c|c|c|c|}
\hline \multirow[b]{2}{*}{ Reference } & \multirow[b]{2}{*}{ Country } & \multicolumn{3}{|c|}{ Population Characteristics } & \multicolumn{3}{|c|}{ Intervention Characteristics } & \multicolumn{4}{|c|}{ Outcome: Arterial Stiffness } \\
\hline & & $\begin{array}{c}\text { Sample Size } \\
(\% \text { Female })\end{array}$ & Mean Age (Years) & $\begin{array}{c}\text { Type of } \\
\text { Population }\end{array}$ & $\begin{array}{c}\text { Type of } \\
\text { Vitamins }\end{array}$ & $\begin{array}{l}\text { Oral Supplement } \\
\text { dose (Frequency) }\end{array}$ & $\begin{array}{c}\text { Length } \\
\text { (Weeks) }\end{array}$ & $\begin{array}{l}\text { Type of } \\
\text { PWv }\end{array}$ & PWv Device & $\begin{array}{l}\text { Basal PWv } \\
\text { Levels (m/s) }\end{array}$ & $\begin{array}{c}\text { \% Change } \\
(\mathrm{m} / \mathrm{s})\end{array}$ \\
\hline $\begin{array}{l}\text { Pilz et al., } 2015 \\
{[46]}\end{array}$ & Germany & $\begin{array}{l}\text { IG: } 100(46.0) \\
\text { CG: } 199(48.0)\end{array}$ & $\begin{array}{l}\text { IG: } 60.5 \pm 10.9 \\
\text { CG: } 59.7 \pm 11.4\end{array}$ & HT & $\begin{array}{c}\text { Cholecalciferol } \\
\text { (vit. D3) }\end{array}$ & 2800 IU (daily) & 8 & NA & NA & $\begin{array}{l}\text { IG: } 8.4 \pm 2.0 \\
\text { CG: } 8.3 \pm 2.1\end{array}$ & $\begin{array}{l}\text { IG: } 1.0 \% \\
\text { CG: } 4.1 \%\end{array}$ \\
\hline $\begin{array}{l}\text { Witham et al., } \\
2015 \text { [47] }\end{array}$ & $\begin{array}{c}\text { United } \\
\text { Kingdom }\end{array}$ & $\begin{array}{l}\text { IG: } 25 \text { (72.0) } \\
\text { CG: } 25 \text { (80.0) }\end{array}$ & $\begin{array}{l}\text { IG: } 48.1 \pm 12.0 \\
\text { CG: } 50.7 \pm 13.1\end{array}$ & $\begin{array}{l}\text { Chronic fatigue } \\
\text { syndrome }\end{array}$ & $\begin{array}{l}\text { Cholecalciferol } \\
\text { (vit. D3) }\end{array}$ & $\begin{array}{c}\text { 100,000 IU (single } \\
\text { dose) }\end{array}$ & 24 & cf-PWv & SphygmoCor & $\begin{array}{l}\text { IG: } 7.3 \pm 2.6 \\
\text { CG: } 8.3 \pm 1.9\end{array}$ & $\begin{array}{l}\text { IG: }-5.5 \% \\
\text { CG: }-2.4 \%\end{array}$ \\
\hline $\begin{array}{l}\text { Bressendorff } \\
\text { et al., 2016 [48] }\end{array}$ & Denmark & $\begin{array}{l}\text { IG: } 22(50) \\
\text { CG: } 18 \text { (34) }\end{array}$ & $\begin{array}{l}\text { IG: } 41.0 \pm 9.1 \\
\text { CG: } 44.5 \pm 8.5\end{array}$ & Healthy & $\begin{array}{c}\text { Cholecalciferol } \\
\text { (vit. D3) }\end{array}$ & 3000 IU (daily) & 16 & cf-PWv & SphygmoCor & $\begin{array}{l}\text { IG: } 6.4 \pm 1.4 \\
\text { CG: } 6.7 \pm 0.9\end{array}$ & $\begin{array}{c}\text { IG: } 0.0 \% \\
\text { CG: }-1.5 \%\end{array}$ \\
\hline $\begin{array}{l}\text { Kumar et al., } \\
2017 \text { [49] }\end{array}$ & $\begin{array}{l}\text { United } \\
\text { Kingdom }\end{array}$ & $\begin{array}{l}\text { IG: } 58(29.3) \\
\text { CG: } 59(32.2)\end{array}$ & $\begin{array}{l}\text { IG: } 43.2 \pm 11.8 \\
\text { CG: } 45.2 \pm 11.6\end{array}$ & CKD & $\begin{array}{l}\text { Cholecalciferol } \\
\text { (vit. D3) }\end{array}$ & $\begin{array}{l}\text { 300,000 IU (two } \\
\text { doses: baseline } \\
\text { and 8weeks) }\end{array}$ & 16 & cf-PWv & SphygmoCor & $\begin{array}{l}\text { IG: } 8.0 \pm 1.6 \\
\text { CG: } 8.0 \pm 1.7\end{array}$ & $\begin{array}{c}\text { IG: }-11.8 \% \\
\text { CG: } 3.8 \%\end{array}$ \\
\hline $\begin{array}{l}\text { Sluyter et al., } \\
2017 \text { [50] }\end{array}$ & $\begin{array}{l}\text { New } \\
\text { Zealand }\end{array}$ & $\begin{array}{l}\text { IG: } 256(40.0) \\
\text { CG: } 261(48.0)\end{array}$ & $\begin{array}{l}\text { IG: } 64.5 \pm 8.3 \\
\text { CG: } 65.5 \pm 8.8\end{array}$ & HT, DM & $\begin{array}{l}\text { Cholecalciferol } \\
\text { (vit. D3) }\end{array}$ & $\begin{array}{l}200,000 \text { IU (single } \\
\text { dose) + 100,000 IU } \\
\text { (monthly) }\end{array}$ & 48 & $\mathrm{a}-\mathrm{PWv}$ & $\begin{array}{l}\text { Mobil-O- } \\
\text { Graph }\end{array}$ & $\begin{array}{l}\text { IG: } 9.3 \pm 1.7 \\
\text { CG: } 9.3 \pm 1.7\end{array}$ & $\begin{array}{l}\text { IG: }-1.1 \% \\
\text { CG: } 0.0 \%\end{array}$ \\
\hline $\begin{array}{l}\text { Gepner et al., } \\
2012 \text { [51] }\end{array}$ & $\begin{array}{l}\text { United } \\
\text { States }\end{array}$ & $\begin{array}{l}\text { IG: } 57(100) \\
\text { CG: } 57(100)\end{array}$ & $\begin{array}{l}\text { IG: } 64.1 \pm 3.0 \\
\text { CG: } 63.6 \pm 3.1\end{array}$ & Postmenopausal & $\begin{array}{l}\text { Cholecalciferol } \\
\text { (vit. D3) }\end{array}$ & 2500 IU (daily) & 16 & cf-PWv & SphygmoCor & $\begin{array}{l}\text { IG: } 7.8 \pm 0.9 \\
\text { CG: } 8.0 \pm 1.4\end{array}$ & $\begin{array}{l}\text { IG: }-1.0 \% \\
\text { CG: } 0.0 \%\end{array}$ \\
\hline $\begin{array}{l}\text { Levin et al., } \\
2017 \text { [52] }\end{array}$ & Canada & $\begin{array}{l}\text { IG1: } 39(28.0) \\
\text { IG2: } 40(30.0) \\
\text { CG: } 40(27.0)\end{array}$ & $\begin{array}{l}\text { IG1: } 66.9 \pm 11.7 \\
\text { IG2: } 65.9 \pm 15.3 \\
\text { CG: } 64.5 \pm 12.2\end{array}$ & CKD & $\begin{array}{l}\text { IG1: Calcitriol } \\
\text { (vit. D) } \\
\text { IG2: Cholecal- } \\
\text { ciferol } \\
\text { (vit. D3) }\end{array}$ & $\begin{array}{c}\text { IG1: } 0.5 \mu \mathrm{g} \text { (thrice } \\
\text { weekly) } \\
\text { IG2: } 5000 \text { IU } \\
\text { (thrice weekly) }\end{array}$ & 24 & cf-PWv & SphygmoCor & $\begin{array}{l}\text { IG1: } 11.6 \pm 3.8 \\
\text { IG2: } 12.2 \pm 4.2 \\
\text { CG: } 10.7 \pm 3.7\end{array}$ & $\begin{array}{l}\text { IG1: } 5.2 \% \\
\text { IG2: } 1.6 \% \\
\text { CG: }-1.0 \%\end{array}$ \\
\hline $\begin{array}{l}\text { Rasool et al., } \\
2006 \text { [54] }\end{array}$ & Malaysia & $\begin{array}{l}\text { IG1: } 9(0.0) \\
\text { IG2: } 9(0.0) \\
\text { IG3: } 9(0.0) \\
\text { CG: } 9(0.0)\end{array}$ & $\begin{array}{l}\text { IG1: } 21-30 \\
\text { IG2: } 21-30 \\
\text { IG3: } 21-30 \\
\text { CG: } 21-30\end{array}$ & Healthy & $\begin{array}{c}\text { Tocotrienol } \\
\text { (vit. E) }\end{array}$ & $\begin{array}{c}\text { IG1: } \\
\text { 80 mg (daily) } \\
\text { IG2: } 160 \mathrm{mg} \text { (daily) } \\
\text { IG3: } 320 \mathrm{mg} \text { (daily) }\end{array}$ & 8 & cf-PWv & SphygmoCor & $\begin{array}{l}\text { IG1: } 7.4 \pm 0.7 \\
\text { IG2: } 7.8 \pm 0.7 \\
\text { IG3: } 7.5 \pm 0.6 \\
\text { CG: } 7.8 \pm 0.8\end{array}$ & $\begin{array}{c}\text { IG1: } 1.3 \% \\
\text { IG2: }-2.6 \% \\
\text { IG3: }-4.0 \% \\
\text { CG: }-1.3 \% \\
\end{array}$ \\
\hline $\begin{array}{l}\text { Stonehouse } \\
\text { et al., 2016 [55] }\end{array}$ & Australia & $\begin{array}{l}\text { IG: } 28 \text { (35.7) } \\
\text { CG: } 29(37.9)\end{array}$ & $\begin{array}{c}\text { IG: } 60.5(56.5-65.8) \\
\text { CG: } 61.0 \\
(56.0-64.0)\end{array}$ & DM2 & $\begin{array}{l}\text { Tocotrienol } \\
\text { (vit. E) }\end{array}$ & 420 mg (daily) & 8 & cf-PWv & Millar SPT-301 & $\begin{array}{l}\text { IG: } 6.8(5.9-7.6) \\
\text { CG: } 7.2(6.3-8.1)\end{array}$ & $\begin{array}{l}\text { IG: }-7.0 \% \\
\text { CG: }-13.3 \%\end{array}$ \\
\hline
\end{tabular}

Data are shown as mean \pm standard deviation (SD) or median (interquartile range); a-PWv: aortic pulse wave velocity; br-PWv: brachial-to-radial pulse wave velocity; cf-PWv: carotid-to-femoral pulse wave velocity; CG: control group; CHF: chronic heart failure; CKD: chronic kidney disease; cr-PWv: carotid-to-radial pulse wave velocity; DM: diabetes mellitus; HT: hypertension; IG: intervention group; NA: not available; PWv: pulse wave velocity; RCT: randomized controlled trial. 


\section{Results}

\subsection{Study Characteristics}

A total of 22 studies [34-55] were included in this NMA (Figure 1). All studies were RCTs. The studies were published between 2002 and 2017 and were conducted in eight different countries, with the United Kingdom being the most frequently reported. The sample size of the studies ranged from 9 to 261 healthy or unhealthy adults (aged 21.0 to 72.0 years). The interventions ranged from 4 to 48 weeks, and the oral vitamin supplementation interventions included two studies for vitamin B9 171 [34,35], two studies for vitamin C [36,37], one study for vitamin D [52], three studies for vitamin D2 [38-40], fifteen studies for vitamin D3 [39-53], and two studies for vitamin E [54,55]. Regarding the type of PWv measured, different methods were included-namely, thirteen for cf.-PWv [34,35,40,41,43,45,47-49,51,52,54,55], five for a-PWv [38,39,42,50,53], one for baPWv [37], one for br-PWv [36], and one for cr-PWv [44]. The characteristics of the included studies are shown in Table 1.

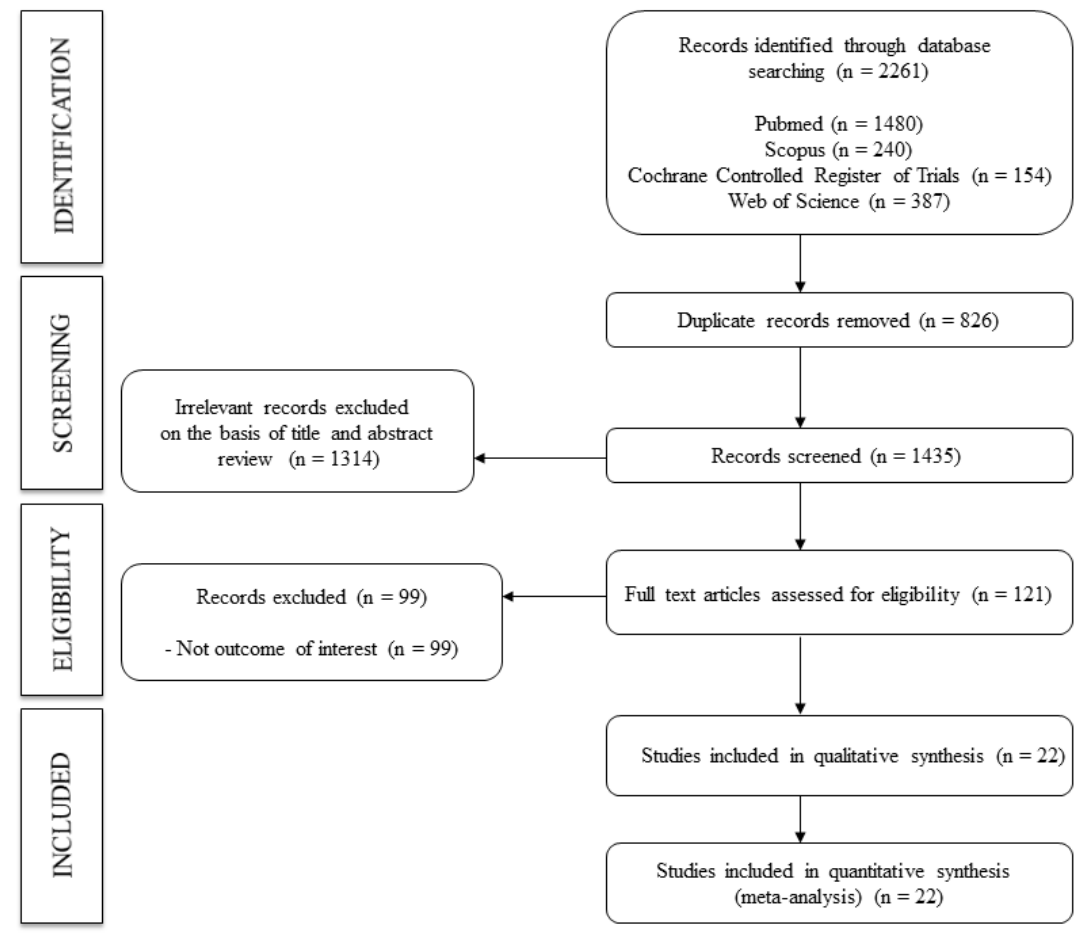

Figure 1. Flowchart.

\subsection{Risk of Bias and GRADE}

For the overall risk of bias $77.3 \%$ of the studies showed some concerns and $22.7 \%$ of the studies had a low risk of bias. With respect to specific domains, in the domain of randomization process, $86.4 \%$ of the studies were rated as low bias; in the domains of deviations from intended interventions, the missing outcome and the measuring of the outcome, $50.0 \%, 36.4 \%$, and $36.4 \%$ of the studies, respectively, were rated as some concerns; finally, in the domain of reported results, $100.0 \%$ of the studies were rated as low risk of bias (Figures S1 and S2).

When the GRADE was evaluated, $75.0 \%$ of the pairwise comparison studies were rated as moderate and $25.0 \%$ as low (Table S2).

\subsection{Effect of Oral Vitamin Supplementation on Arterial Stiffness}

Figure 2 displays the network geometry plot of the comparisons testing the effect of different oral vitamin supplementation interventions on arterial stiffness. Table 2 displays the ES estimates from direct studies separately (upper diagonal) from the indirect ES estimates (lower diagonal). In the pairwise analyses, although no significant results 
were shown, compared with the placebo group, all estimates were in favor of oral vitamin supplementation interventions, with the exceptions of vitamins $C$ and $E$. In addition, oral vitamin D3 supplementation proved to be a better supplement for decreasing arterial stiffness than vitamin D2 supplementation (ES: $-0.25 ; 95 \% \mathrm{CI}:-0.48,-0.02 ;-36.0 \% \mathrm{~m} / \mathrm{s}$ ). In the frequentist NMA, no significant results were shown; however, oral vitamin supplementation interventions are in favor of reducing arterial stiffness, with the exception of vitamins $\mathrm{C}$ and $\mathrm{E}$.

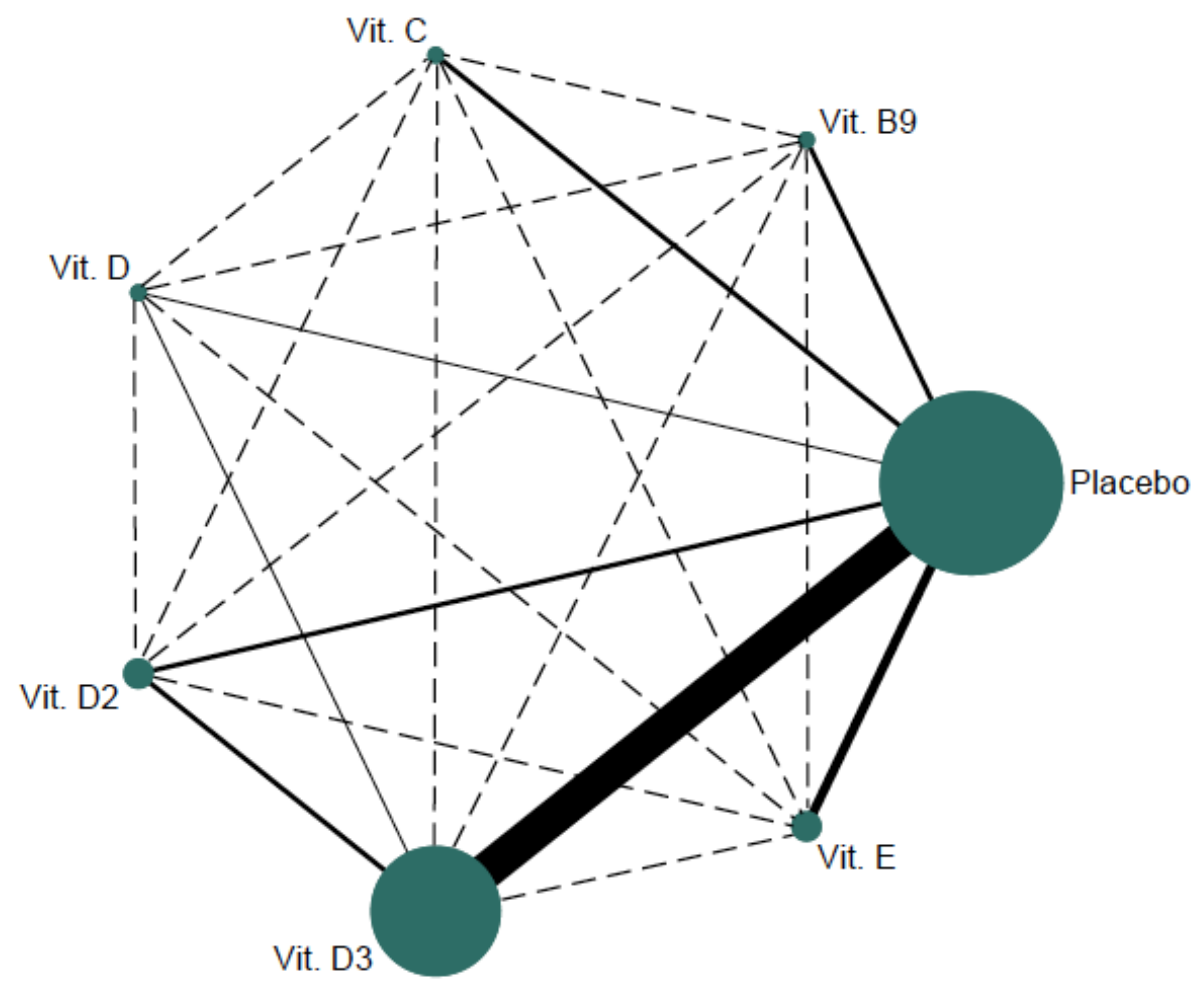

Figure 2. Network of available comparisons between different types of oral vitamin supplements in arterial stiffness.

Table 2. Pooled mean differences in different types of oral vitamin supplements on arterial stiffness.

\begin{tabular}{|c|c|c|c|c|c|c|}
\hline Placebo & $\begin{array}{c}-0.14 \\
(-0.69,0.42)\end{array}$ & $\begin{array}{c}0.17 \\
(-0.29,0.63)\end{array}$ & $\begin{array}{c}-0.04 \\
(-0.56,0.47)\end{array}$ & $\begin{array}{c}-0.24 \\
(-0.50,0.01)\end{array}$ & $\begin{array}{c}-0.08 \\
(-0.24,0.08)\end{array}$ & $\begin{array}{c}0.20 \\
(-0.17,0.58)\end{array}$ \\
\hline $\begin{array}{c}-0.13 \\
(-1.02,0.77)\end{array}$ & $\begin{array}{l}\text { Folic acid } \\
\text { (vit. B9) }\end{array}$ & NA & NA & NA & NA & NA \\
\hline $\begin{array}{c}0.36 \\
(-0.52,1.24)\end{array}$ & $\begin{array}{c}0.49 \\
(-0.77,1.74)\end{array}$ & $\begin{array}{l}\text { Ascorbic acid } \\
\text { (vit. C) }\end{array}$ & NA & NA & NA & NA \\
\hline $\begin{array}{c}-0.01 \\
(-0.63,0.61)\end{array}$ & $\begin{array}{c}0.12 \\
(-0.97,1.21) \\
\end{array}$ & $\begin{array}{c}-0.37 \\
(-1.44,0.71)\end{array}$ & $\begin{array}{c}\text { Calcitriol } \\
\text { (vit. D) }\end{array}$ & NA & $\begin{array}{c}-0.32 \\
(-0.84,0.20)\end{array}$ & NA \\
\hline $\begin{array}{c}-0.10 \\
(-0.73,0.54)\end{array}$ & $\begin{array}{c}0.03 \\
(-1.07,1.13) \\
\end{array}$ & $\begin{array}{c}-0.45 \\
(-1.54,0.63)\end{array}$ & $\begin{array}{c}-0.09 \\
(-0.96,0.79)\end{array}$ & $\begin{array}{l}\text { Ergocalciferol } \\
\text { (vit. D2) }\end{array}$ & $\begin{array}{c}-0.25 \\
(-0.48,-0.02)\end{array}$ & NA \\
\hline $\begin{array}{c}-0.21 \\
(-0.54,0.11)\end{array}$ & $\begin{array}{c}-0.09 \\
(-1.04,0.86)\end{array}$ & $\begin{array}{c}-0.57 \\
(-1.51,0.36)\end{array}$ & $\begin{array}{c}-0.21 \\
(-0.87,0.45)\end{array}$ & $\begin{array}{c}-0.12 \\
(-0.76,0.52)\end{array}$ & $\begin{array}{c}\text { Cholecalciferol } \\
\text { (vit. D3) }\end{array}$ & NA \\
\hline $\begin{array}{c}0.28 \\
(-0.36,0.92)\end{array}$ & $\begin{array}{c}0.41 \\
(-0.69,1.51)\end{array}$ & $\begin{array}{c}-0.08 \\
(-1.17,1.01)\end{array}$ & $\begin{array}{c}0.29 \\
(-0.60,1.18)\end{array}$ & $\begin{array}{c}0.38 \\
(-0.53,1.28)\end{array}$ & $\begin{array}{c}0.50 \\
(-0.22,1.22)\end{array}$ & $\begin{array}{c}\text { Tocotrienol } \\
\text { (vit. E) }\end{array}$ \\
\hline
\end{tabular}




\subsection{Probabilities}

Oral supplementation with vitamin B9 was more likely to be the best $(31.0 \%)$, and oral supplementation with vitamin D3 showed a higher SUCRA value (78.0\%) (Figure S3 and Table S3).

Oral supplements with vitamin D3 versus the placebo group showed substantial heterogeneity $(\mathrm{I} 2=63.4 \%, \tau 2=0.06)$. The other direct comparisons showed no heterogeneity $(\mathrm{I} 2=0.0, \tau 2=0.00)($ Table S4).

\subsection{Sensitivity Analysis, Subgroup Analyses, Meta-Regression Models, and Publication Bias}

The estimate of the pooled ES was not significantly changed (either in magnitude or direction) when data from individual studies were eliminated from the analysis one study at a time.

Subgroup analyses based on mean age ( $<65$ years or $>65$ years) showed that oral supplementation with vitamin D3 was effective in reducing arterial stiffness, compared with oral supplementation with vitamin D2 in adults <65 years (ES: -0.30 ; 95\% CI: $-0.57,-0.03$; $-58.0 \% \mathrm{~m} / \mathrm{s}$ ) (Table S5). Subgroup analysis based on length of intervention $(<12$ weeks or $>12$ weeks) showed that oral supplementation with vitamin D3, compared with the placebo group, and oral supplementation with vitamin D3, compared with oral supplementation with vitamin D2, were effective in reducing arterial stiffness for interventions $>12$ weeks (ES: -0.15 ; 95\% CI: $-0.30,-0.00 ;-60.0 \% \mathrm{~m} / \mathrm{s}$; and ES: $-0.25 ; 95 \% \mathrm{CI}:-0.48$, $-0.02,-52.0 \% \mathrm{~m} / \mathrm{s}$, respectively) (Table S6). For subgroup analyses based on the type of PWv (central or peripheral PWv), central PWv showed significant results in oral supplementation with vitamin D3, compared with oral supplementation with vitamin D2 (ES: $-0.25 ; 95 \%$ CI: $-0.48,-0.02 ;-36.0 \% \mathrm{~m} / \mathrm{s}$ ) (Table S7). For subgroup analyses based on the type of vitamins (water soluble or fat soluble), no significant results were shown (Table S8).

Meta-regression models showed that mean age and length of intervention intensity did not modify the effect of oral supplementation with vitamin D3 vs. placebo on arterial stiffness (Table S9). Other comparisons were not performed because of an insufficient number of studies.

No publication bias was shown in the included comparisons (Figure S4).

\section{Discussion}

This NMA provides an overview of the evidence comparing different types of oral vitamin supplements on arterial stiffness. Our findings showed that even though overall, the different types of oral vitamin supplements showed no statistically significant effects, when oral vitamin supplementation was longer than 12 weeks, vitamin D3 showed a significant reduction in central arterial stiffness, compared with placebo $(-60.0 \% \mathrm{~m} / \mathrm{s})$ and vitamin D2 (-52.0\% m/s).

Consistent with our results, previous systematic reviews $[16,18,23]$ that summarize the effect of oral vitamin supplement types on arterial stiffness show controversial results since there is no consensus among the findings in these systemic reviews. However, this NMA was designed to report the pooled results of the effects of different types of oral vitamin supplements on arterial stiffness and to provide evidence consistent with previous reviews.

Our findings show that vitamin D3 supplementation (by continuous intake for more than 12 weeks) is effective in reducing central arterial stiffness. This may be because endothelial cells present a vitamin D receptor and several enzymes capable of converting the circulating form of vitamin D (25-hydroxyvitamin) into the active form (1,25-dihydroxyvitamin D, ergocalciferol, or cholecalciferol) [56,57]. Thus, vitamin D2 and D3 can regulate endothelial and smooth muscle cell function by different mechanisms [58], with evidence showing a greater effect of vitamin D3 than vitamin D2, possibly because vitamin D3 maintains adequate vitamin D levels in the blood for a longer period of time $[39,40]$. Among the different functions modulated by vitamin D are antiproliferative effects on vascular smooth muscle, lymphocyte and monocyte differentiation, the release of proinflammatory cytokines [59], and modulation of the renin-angiotensin-aldosterone 
system [60]. These processes contribute to arterial stiffness and can induce monocyte infiltration into the vascular wall [61,62].

Looking at the results shown by the network geometry graph, we can see that there is ample evidence supporting the effectiveness of vitamin D3 in reducing central arterial stiffness. However, there are a small number of RCTs on other types of oral vitamin supplements, such as other forms of vitamin D and vitamins E, C, and B9, making it difficult to draw conclusions about whether these vitamins might also be effective. However, based on the findings of this study, it is evident that vitamins $C$ and E could increase arterial stiffness (although not statistically significant), which would be conflicting with the current evidence [63-65]. Although previous studies support that vitamins $C$ and $E$ have no immediate effect on arterial stiffness, over time, they increase arterial stiffness [66,67]. Therefore, our results should be cautiously considered, until further RCTs are performed to clarify the direction of the effects of these vitamins.

This NMA has some limitations that should be acknowledged. First, the limited number of samples included in the assessment of some types of oral vitamin supplements and the likelihood that unpublished studies of these types of oral vitamin supplements might have changed the findings of the meta-analysis. Second, the findings of this NMA were derived after some manipulation of the data (ES of the raw data from the included studies), which might lead to some bias. Third, a wide variety of measurements of PWv (a-PWv, ba-PWv, br-PWv, cf.-PWv, and cr-PWv) were used, which may limit the implications of the results. Fourth, the overall risk of bias for RCTs showed some concerns of bias in most studies. Fifth, studies performed in different types of populations were included in the NMA (healthy, diabetes, hypertension, etc.); therefore, our results should be interpreted with caution. Sixth, because studies include different information on dose, frequency, and duration of treatment with oral vitamin supplements, it is not possible to estimate the threshold dose of vitamin D3 for PWv reduction. Finally, our findings are driven by the analysis of the effect of oral vitamin supplementation on PWv reduction, with consistent evidence supporting that PWv is a good predictor of CVD, CVD mortality, and all-cause mortality, with all the clinical and epidemiological consequences that this implies.

\section{Conclusions}

In conclusion, our study supports that oral vitamin D3 supplementation for more than 12 weeks could be an effective approach to reduce central arterial stiffness. Our findings are based on data from experimental studies and provide the best currently existing evidence of the effects of oral vitamin supplementation on arterial stiffness as a therapeutic and preventive strategy. However, future well-designed and statistically powered RCTs are essential to reinforce the currently limited evidence to reflect that, over time, patients at high risk of CVD could benefit from the effects of oral vitamin supplementation, specifically vitamin D3, as a useful strategy to improve their vascular health.

Supplementary Materials: The following supporting information can be downloaded at: https:/ / www.mdpi.com/article/10.3390/nu14051009/s1, Figure S1: Quality assessment using the Cochrane Collaboration tool for assessing risk of bias in randomized clinical trials (RoB2) for each study, Figure S2: Overall quality assessment, Figure S3: Rankogram for each of different types of oral vitamin supplements on arterial stiffness, Figure S4: Funnel plot for comparison-specific pooled mean differences, Table S1: Search strategy for the MEDLINE database, Table S2: Quality grading of evidence, Table S3: Effectiveness ranking of different types of oral vitamin supplements on arterial stiffness, Table S4: Heterogeneity statistics for each comparison, Table S5: Subgroup analysis according to mean age ( $<65$ years or $>65$ years) by type of vitamin on arterial stiffness, Table S6: Subgroup analysis according to length of intervention by type of vitamin on arterial stiffness, Table S7: Subgroup analysis according to type of pulse wave velocity by type of vitamin, Table S8: Subgroup analysis according to type of vitamin (water soluble or fat soluble) on arterial stiffness, Table S9: Meta-regression according to mean age and length of intervention for vitamin D3 vs. placebo on arterial stiffness. 
Author Contributions: Conceptualization, A.S.-L. and I.C.-R.; methodology, A.S.-L., B.N.-P. and I.C.-R.; software, I.C.-R. and B.N.-P.; validation, C.P.-M. and I.A.M.-O.; formal analysis, A.S.-L. and B.N.-P.; investigation, A.S.-L. and I.C.-R.; resources, A.S.-L., C.P.-M. and I.A.M.-O.; data curation, I.C.-R. and V.M.-V.; writing-original draft preparation, A.S.-L. and I.C.-R.; writing-review and editing, V.M.-V.; visualization, C.P.-M. and I.A.M.-O.; supervision, I.C.-R. All authors have read and agreed to the published version of the manuscript.

Funding: This research was funded by FEDER funds. A.S.-L. is supported by a grant from the University of Castilla-La Mancha (2019-PREDUCLM-10708). C.P.-M. is supported by a grant from the University of Castilla-La Mancha (2018-CPUCLM-7939).

Conflicts of Interest: The authors declare no conflict of interest.

\section{References}

1. Cunha, P.G.; Cotter, J.; Oliveira, P.; Vila, I.; Boutouyrie, P.; Laurent, S.; Nilsson, P.M.; Scuteri, A.; Sousa, N. Pulse wave velocity distribution in a cohort study: From arterial stiffness to early vascular aging. J. Hypertens. 2015, 33, 1438-1445. [CrossRef] [PubMed]

2. Vlachopoulos, C.; Aznaouridis, K.; Stefanadis, C. Prediction of cardiovascular events and all-cause mortal- ity with arterial stiffness: A systematic review and meta-analysis. J. Am. Coll. Cardiol. 2010, 55, 1318-1327. [CrossRef] [PubMed]

3. Schnabel, R.; Larson, M.G.; Dupuis, J.; Lunetta, K.L.; Lipinska, I.; Meigs, J.B.; Yin, X.; Rong, J.; Vita, J.A.; Newton-Cheh, C.; et al. Relations of inflammatory biomarkers and common genetic variants with arterial stiffness and wave reflection. Hypertension 2008, 51, 1651-1657. [CrossRef] [PubMed]

4. Willum-Hansen, T.; Staessen, J.A.; Torp-Pedersen, C.; Rasmussen, S.; Thijs, L.; Ibsen, H.; Jeppesen, J. Prognostic value of aortic pulse wave velocity as index of arterial stiffness in the general population. Circulation 2006, 113, 663-664. [CrossRef] [PubMed]

5. Laurent, S.; Cockcroft, J.; Van Bortel, L.; Boutouyrie, P.; Giannattasio, C.; Hayoz, D.; Pannier, B.; Vlachopoulos, C.; Wilkinson, I.; Struijker-Boudier, H. Expert consensus document on arterial stiffness: Methodological issues and clinical applications. Eur. Heart J. 2006, 27, 2588-2605. [CrossRef]

6. Ben-Shlomo, Y.; Spears, M.; Boustred, C.; May, M.; Anderson, S.G.; Benjamin, E.J.; Boutouyrie, P.; Cameron, J.; Chen, C.H.; Cruickshank, J.K.; et al. Aortic pulse wave velocity improves cardiovascular event prediction: An individual participant meta-analysis of prospective observational data from 17,635 subjects. J. Am. Coll. Cardiol. 2014, 63, 636-646. [CrossRef]

7. Woznicka-Leskiewicz, L.; Posadzy-Malaczynska, A.; Juszkat, R. The impact of ankle brachial index and pulse wave velocity on cardiovascular risk according to SCORE and Framingham scales and sex differences. J. Hum. Hypertens. 2015, 29, 502-510. [CrossRef]

8. Arnett, D.K.; Blumenthal, R.S.; Albert, M.A.; Buroker, A.B.; Goldberger, Z.D.; Hahn, E.J.; Himmelfarb, C.D.; Khera, A.; Lloyd-Jones, D.; McEvoy, J.W.; et al. 2019 ACC/AHA guideline on the primary prevention of cardiovascular disease: A report of the American College of Cardiology / American Heart Association Task Force on Clinical Practice Guidelines. J. Am. Coll. Cardiol. 2019, 74, e177-e232. [CrossRef]

9. Mao, X.; Xing, X.; Xu, R.; Gong, Q.; He, Y.; Li, S.; Wang, H.; Liu, C.; Ding, X.; Na, R.; et al. Folic acid and vitamins D and B12 correlate with homocysteine in chinese patients with type 2 diabetes mellitus, hypertension, or cardiovascular disease. Medicine 2016, 95, e2652. [CrossRef]

10. McGreevy, C.; Williams, D. New insights about vitamin D and cardiovascular disease: A narrative review. Ann. Intern. Med. 2011, 155, 820-826. [CrossRef]

11. Waśkiewicz, A.; Szcześniewska, D.; Szostak-Węgierek, D.; Kwaśniewska, M.; Pająk, A.; Stepaniak, U.; Kozakiewicz, K.; Tykarski, A.; Zdrojewski, T.; Zujko, M.E.; et al. Are dietary habits of the Polish population consistent with the recommendations for prevention o cardiovascular disease? WOBASZ II Project. Kardiol. Pol. 2016, 74, 969-977. [CrossRef] [PubMed]

12. Zureik, M.; Galan, P.; Bertrais, S.; Mennen, L.; Czernichow, S.; Blacher, J.; Ducimetière, P.; Hercberg, S. Effects of long-term daily low-dose supplementation with antioxidant vitamins and minerals on structure and function of large arteries. Arterioscler. Thromb. Vasc. Biol. 2004, 24, 1485-1491. [CrossRef] [PubMed]

13. Shargorodsky, M.; Debby, O.; Matas, Z.; Zimlichman, R. Effect of long-term treatment with antioxidants (vitamin C, vitamin E, coenzyme Q10 and selenium) on arterial compliance, humoral factors and inflammatory markers in patients with multiple. cardiovascular risk factors. Nutr. Metab. 2010, 7, 55. [CrossRef] [PubMed]

14. Estruch, R.; Ros, E.; Salas-Salvadó, J.; Covas, M.I.; Corella, D.; Arós, F.; Gómez-Gracia, E.; Ruiz-Gutiérrez, V.; Fiol, M.; Lapetra, J.; et al. Primary prevention of cardiovascular disease with a Mediterranean diet. N. Engl. J. Med. 2013, 368, 1279-1290. [CrossRef] [PubMed]

15. Schwingshackl, L.; Hoffmann, G.; Buijsse, B.; Mittag, T.; Stelmach-Mardas, M.; Boeing, H.; Gottschald, M.; Dietrich, S.; Arregui, M.; Dias, S. Dietary supplements and risk of causespecific death, cardiovascular disease, and cancer: A protocol for a systematic review and network meta-analysis of primary prevention trials. Syst. Rev. 2015, 4, 34. [CrossRef]

16. Ashor, A.W.; Siervo, M.; Lara, J.; Oggioni, C.; Mathers, J.C. Antioxidant vitamin supplementation reduces arterial stiffness in adults: A systematic review and metaanalysis of randomized controlled trials. J. Nutr. 2014, 144, 594-602. [CrossRef] [PubMed] 
17. Ashor, A.W.; Lara, J.; Mathers, J.C.; Siervo, M. Effect of vitamin C on endothelial function in health and disease: A systematic review and meta-analysis of randomised controlled trials. Atherosclerosis 2014, 235, 9-20. [CrossRef]

18. Rodríguez, A.J.; Scott, D.; Srikanth, V.; Ebeling, P. Effect of vitamin D supplementation on measures of arterial stiffness: A systematic review and meta-analysis of randomized controlled trials. Clin. Endocrinol. 2016, 84, 645-657. [CrossRef]

19. Beveridge, L.A.; Khan, F.; Struthers, A.D.; Armitage, J.; Barchetta, I.; Bressendorff, I.; Cavallo, M.G.; Clarke, R.; Dalan, R.; Dreyer, G.; et al. Effect of Vitamin D Supplementation on Markers of Vascular Function: A Systematic Review and Individual Participant Meta-Analysis. J. Am. Heart Assoc. 2018, 7, e008273. [CrossRef]

20. Tabrizi, R.; Vakili, S.; Lankarani, K.B.; Akbari, M.; Jamilian, M.; Mahdizadeh, Z.; Mirhosseini, N.; Asemi, Z. The Effects of Vitamin D Supplementation on Markers Related to Endothelial Function Among Patients with Metabolic Syndrome and Related Disorders: A Systematic Review and Meta-Analysis of Clinical Trials. Horm. Metab. Res. 2018, 50, 587-596. [CrossRef]

21. Dou, D.; Yang, B.; Gan, H.; Xie, D.; Lei, H.; Ye, N. Vitamin D supplementation for the improvement of vascular function in patients with chronic kidney disease: A metaanalysis of randomized controlled trials. Int. Urol. Nephrol. 2019, 51, 851-858. [CrossRef] [PubMed]

22. Pincombe, N.L.; Pearson, M.J.; Smart, N.A.; King, N.; Dieberg, G. Effect of vitamin D supplementation on endothelial functionAn updated systematic review with metaanalysis and meta-regression. Nutr. Metab. Cardiovasc Dis. 2019, 29, $1261-1272$. [CrossRef] [PubMed]

23. Chen, N.C.; Hsu, C.Y.; Mao, P.C.; Dreyer, G.; Wu, F.Z.; Chen, C.L. The effects of correction of vitamin D deficiency on arterial stiffness: A systematic review and updated metaanalysis of randomized controlled trials. J. Steroid Biochem. Mol. Biol. 2020, 198, 105561. [CrossRef] [PubMed]

24. Hutton, B.; Catala-Lopez, F.; Moher, D. The PRISMA statement extension for systematic reviews incorporating network metaanalysis: PRISMA-NMA. Med. Clin. 2016, 147, 262-266. [CrossRef] [PubMed]

25. Higgins, J.P.; Green, S. Cochrane Handbook for Systematic Reviews of Interventions. 2008. Updated March 2011. Available online: https:/ / handbook-5-1.cochrane.org/ (accessed on 20 December 2021).

26. Higgins, J.P.; Sterne, J.A.; Savovic, J.; Page, M.J.; Hróbjartsson, A.; Boutron, I.; Reeves, B.; Eldridge, S. A revised tool for assessing risk of bias in randomized trials. Cochrane Database Syst. Rev. 2016, 10, 29-31.

27. Guyatt, G.H.; Oxman, A.D.; Schünemann, H.J.; Tugwell PKnottnerus, A. GRADE guidelines: A new series of articles in the Journal of Clinical Epidemiology. J. Clin. Epidemiol. 2011, 64, 380-382. [CrossRef]

28. Salanti, G.; Ades, A.E.; Ioannidis, J.P. Graphical methods and numerical summaries for presenting results from multiple-treatment meta-analysis: An overview and tutorial. J. Clin. Epidemiol. 2011, 64, 163-171. [CrossRef]

29. DerSimonian, R.; Laird, N. Meta-analysis in clinical trials. Control. Clin. Trials 1986, 7, 177-188. [CrossRef]

30. Stettler, C.; Allemann, S.; Wandel, S.; Kastrati, A.; Morice, M.C.; Schömig, A.; Pfisterer, M.E.; Stone, G.W.; Leon, M.B.; de Lezo, J.S.; et al. Drug eluting and bare metal stents in people with and without diabetes: Collaborative network meta-analysis. BMJ 2008, a1331, 337. [CrossRef]

31. Cipriani, A.; Higgins, J.P.; Geddes, J.R.; Salanti, G. Conceptual and technical challenges in network meta-analysis. Ann. Intern. Med. 2013, 159, 130-137. [CrossRef]

32. Chaimani, A.; Higgins, J.P.; Mavridis, D.; Spyridonos, P.; Salanti, G. Graphical tools for network meta-analysis in STATA. PLoS ONE 2013, 8, e76654. [CrossRef] [PubMed]

33. Sterne, J.A.C.; Egger, M.; Smith, G.D. Systematic reviews in health care: Investigating and dealing with publication and other biases in meta-analysis. BMJ 2001, 323, 101-105. [CrossRef] [PubMed]

34. Mangoni, A.A.; Sherwood, R.A.; Swift, C.G.; Jackson, S.H. Folic acid enhances endotelial function and reduces blood pressure in smokers: A randomized controlled trial. J. Intern. Med. 2002, 252, 497-503. [CrossRef] [PubMed]

35. Mangoni, A.A.; Sherwood, R.A.; Asonganyi, B.; Swift, C.G.; Thomas, S.; Jackson, S.H. Shortterm oral folic acid supplementation enhances endothelial function in patients with type 2 diabetes. Am. J. Hypertens. 2005, 18, 220-226. [CrossRef]

36. Nightingale, A.K.; Blackman, D.J.; Field, R.; Glover, N.J.; Pegge, N.; Mumford, C.; Schmitt, M.; Ellis, G.R.; Morris-Thurgood, J.A.; Frenneaux, M.P. Role of nitric oxide and oxidative stress in baroreceptor dysfunction in patients with chronic heart failure. Clin. Sci. 2003, 104, 529-535. [CrossRef]

37. Nightingale, A.K.; Crilley, J.G.; Pegge, N.C.; Boehm, E.A.; Mumford, C.; Taylor, D.J.; Styles, P.; Clarke, K.; Frenneaux, M.P. Chronic oral ascorbic acid therapy worsens skeletal muscle metabolism in patients with chronic heart failure. Eur. J. Heart Fail. 2007, 9 , 287-291. [CrossRef]

38. Dreyer, G.; Tucker, A.T.; Harwood, S.M.; Pearse, R.M.; Raftery, M.J.; Yaqoob, M.M. Ergocalciferol and microcirculatory function in chronic kidney disease and concomitant vitamin d deficiency: An exploratory, double blind, randomised controlled trial. PLoS ONE 2014, 9, e99461. [CrossRef]

39. Kovesdy, C.P.; Lu, J.L.; Malakauskas, S.M.; Andress, D.L.; Kalantar-Zadeh, K.; Ahmadzadeh, S. Paricalcitol versus ergocalciferol for secondary hyperparathyroidism in CKD stages 3 and 4: A randomized controlled trial. Am. J. Kidney Dis. 2012, 59, 58-66. [CrossRef]

40. Forouhi, N.G.; Menon, R.K.; Sharp, S.J.; Mannan, N.; Timms, P.M.; Martineau, A.R.; Rickard, A.P.; Boucher, T.A.; Chowdhury, T.A.; Griffiths, C.J.; et al. Effects of vitamin D2 or D3 supplementation on glycaemic control and cardiometabolic risk among people at risk of type 2 diabetes: Results of a randomized double-blind placebo-controlled trial. Diabetes Obes. Metab. 2016, 18, 392-400. [CrossRef] 
41. Larsen, T.; Mose, F.H.; Bech, J.N.; Hansen, A.B.; Pedersen, E.B. Effect of cholecalciferol supplementation during winter months in patients with hypertension: A randomized, placebo-controlled trial. Am. J. Hypertens. 2012, 25, 1215-1222. [CrossRef]

42. Marckmann, P.; Agerskov, H.; Thineshkumar, S.; Bladbjerg, E.M.; Sidelmann, J.J.; Jespersen, J.; Nybo, M.; Rasmussen, L.M.; Hansen, D.; Scholze, A. Randomized controlled trial of cholecalciferol supplementation in chronic kidney disease patients with hypovitaminosis D. Nephrol. Dial. Transplant. 2012, 27, 3523-3531. [CrossRef] [PubMed]

43. Hewitt, N.A.; O'Connor, A.A.; O'Shaughnessy, D.V.; Elder, G.J. Effects of cholecalciferol on functional, biochemical, vascular, and quality of life outcomes in hemodialysis patients. Clin. J. Am. Soc. Nephrol. 2013, 8, 1143-1149. [CrossRef] [PubMed]

44. Witham, M.D.; Adams, F.; Kabir, G.; Kennedy, G.; Belch, J.J.; Khan, F. Effect of short-term vitamin D supplementation on markers of vascular health in South Asian women living in the UK-a randomised controlled trial. Atherosclerosis 2013, 230, 293-299. [CrossRef] [PubMed]

45. Mose, F.H.; Vase, H.; Larsen, T.; Kancir, A.S.; Kosierkiewic, R.; Jonczy, B.; Hansen, A.B.; Oczachowska-Kulik, A.E.; Thomsen, I.M.; Bech, J.N.; et al. Cardiovascular effects of cholecalciferol treatment in dialysis patients-a randomized controlled trial. $B M C$ Nephrol. 2014, 15, 50. [CrossRef] [PubMed]

46. Pilz, S.; Gaksch, M.; Kienreich, K.; Grübler, M.; Verheyen, N.; Fahrleitner-Pammer, A.; Treiber, G.; Drechsler, C.; ó Hartaigh, B.; Obermayer-Pietsch, B.; et al. Effects of vitamin D on blood pressure and cardiovascular risk factors: A randomized controlled trial. Hypertension 2015, 65, 1195-1201. [CrossRef]

47. Witham, M.D.; Adams, F.; McSwiggan, S.; Kennedy, G.; Kabir, G.; Belch, J.J.; Khan, F. Effect of intermittent vitamin D3 on vascular function and symptoms in chronic fatigue syndrome-a randomised controlled trial. Nutr. Metab. Cardiovasc. Dis. 2015, 25, 287-294. [CrossRef]

48. Bressendorff, I.; Brandi, L.; Schou, M.; Nygaard, B.; Frandsen, N.E.; Rasmussen, K.; Ødum, L.; Østergaard, O.V.; Hansen, D. The Effect of High Dose Cholecalciferol on Arterial Stiffness and Peripheral and Central Blood Pressure in Healthy Humans: A Randomized Controlled Trial. PLoS ONE 2016, 11, e0160905. [CrossRef]

49. Kumar, V.; Yadav, A.K.; Lal, A.; Kumar, V.; Singhal, M.; Billot, L.; Billot, L.; Gupta, K.L.; Banerjee, D.; Jha, V. A Randomized Trial of Vitamin D Supplementation on Vascular Function in CKD. J. Am. Soc. Nephrol. 2017, 28, 3100-3108. [CrossRef]

50. Sluyter, J.D.; Camargo, C.A., Jr.; Stewart, A.W.; Waayer, D.; Lawes, C.M.M.; Toop, L.; Khaw, K.T.; Thom, S.A.; Hametner, B.; Wassertheurer, S.; et al. Effect of Monthly, High-Dose, Long-Term Vitamin D Supplementation on Central Blood Pressure Parameters: A Randomized Controlled Trial Substudy. J. Am. Heart Assoc. 2017, 6, e006802. [CrossRef]

51. Gepner, A.D.; Ramamurthy, R.; Krueger, D.C.; Korcarz, C.E.; Binkley, N.; Stein, J.H. A prospective randomized controlled trial of the effects of vitamin D supplementation on cardiovascular disease risk. PLoS ONE 2012, 7, e36617. [CrossRef]

52. Levin, A.; Tang, M.; Perry, T.; Zalunardo, N.; Beaulieu, M.; Dubland, J.A.; Zerr, K.; Djurdjev, O. Randomized Controlled Trial for the Effect of Vitamin D Supplementation on Vascular Stiffness in CKD. Clin. J. Am. Soc. Nephrol. 2017, 12, 1447-1460. [CrossRef] [PubMed]

53. Tomson, J.; Hin, H.; Emberson, J.; Kurien, R.; Lay, M.; Cox, J.; Cox, J.; Hill, M.; Arnold, L.; Leeson, P.; et al. Effects of Vitamin D on Blood Pressure, Arterial Stiffness, and Cardiac Function in Older People After 1 Year: BEST-D (Biochemical Efficacy and Safety Trial of Vitamin D). J. Am. Heart Assoc. 2017, 6, e005707. [CrossRef] [PubMed]

54. Rasool, A.H.; Yuen, K.H.; Yusoff, K.; Wong, A.R.; Rahman, A.R. Dose dependent elevation of plasma tocotrienol levels and its effect on arterial compliance, plasma total antioxidant status, and lipid profile in healthy humans supplemented with tocotrienol rich vitamin E. J. Nutr. Sci. Vitaminol. 2006, 52, 473-478. [CrossRef] [PubMed]

55. Stonehouse, W.; Brinkworth, G.D.; Thompson, C.H.; Abeywardena, M.Y. Short term effects of palm-tocotrienol and palmcarotenes on vascular function and cardiovascular disease risk: A randomised controlled trial. Atherosclerosis 2016, 254, 205-214. [CrossRef] [PubMed]

56. White, P.; Cooke, N. The multifunctional properties and characteristics of vitamin Dbinding protein. Trends Endocrinol. Metab. 2000, 11, 320-327. [CrossRef]

57. Raymond, M.A.; Désormeaux, A.; Labelle, A.; Soulez, M.; Soulez, G.; Langelier, Y.; Pshezhetsky, A.V.; Hébert, M.J. Endothelial stress induces the release of vitamin Dbinding protein, a novel growth factor. Biochem. Biophys. Res. Commun. 2005, 338, 1374-1382. [CrossRef] [PubMed]

58. Wu-Wong, J.R.; Nakane, M.; Ma, J.; Ruan, X.; Kroeger, P.E. Effects of Vitamin D analogs on gene expression profiling in human coronary artery smooth muscle cells. Atherosclerosis 2006, 186, 20-28. [CrossRef]

59. Zehnder, D.; Bland, R.; Chana, R.S.; Wheeler, D.C.; Howie, A.J.; Williams, M.C.; Stewart, P.M.; Hewison, M. Synthesis of 1, 25-dihydroxyvitamin D3 by human endothelial cells is regulated by inflammatory cytokines: A novel autocrine determinant of vascular cell adhesion. J. Am. Soc. Nephrol. 2002, 13, 621-629. [CrossRef]

60. Li, Y.C.; Kong, J.; Wei, M.; Chen, Z.F.; Liu, S.Q.; Cao, L.P. 1, 25-Dihydroxyvitamin D 3 is a negative endocrine regulator of the renin-angiotensin system. J. Clin. Investig. 2002, 110, 229-238. [CrossRef]

61. Oh, J.; Weng, S.; Felton, S.K.; Bhandare, S.; Riek, A.; Butler, B.; Proctor, B.M.; Petty, M.; Chen, Z.; Schechtman, K.B.; et al. 1, 25 $(\mathrm{OH}) 2$ vitamin D inhibits foam cell formation and suppresses macrophage cholesterol uptake in patients with type 2 diabetes mellitus. Circulation 2009, 120, 687-698. [CrossRef]

62. Riek, A.E.; Oh, J.; Bernal-Mizrachi, C. Vitamin D regulates macrophage colesterol metabolism in diabetes. J. Steroid Biochem. 2010, 121, 430-433. [CrossRef] 
63. Wilkinson, I.B.; Megson, I.L.; MacCallum, H.; Sogo, N.; Cockcroft, J.R.; Webb, D.J. Oral vitamin C reduces arterial stiffness and platelet aggregation in humans. J. Cardiovasc. Pharmacol. 1999, 34, 690-693. [CrossRef] [PubMed]

64. Plantinga, Y.; Ghiadoni, L.; Magagna, A.; Giannarelli, C.; Franzoni, F.; Taddei, S.; Salvetti, A. Supplementation with vitamins C and E improves arterial stiffness and endotelial function in essential hypertensive patients. Am. J. Hypertens. 2007, 20, 392-397. [CrossRef] [PubMed]

65. Mullan, B.A.; Young, I.S.; Fee, H.; McCance, D.R. Ascorbic acid reduces blood pressure and arterial stiffness in type 2 diabetes. Hypertension 2002, 40, 804-809. [CrossRef] [PubMed]

66. Kelly, R.P.; Poo Yeo, K.; Isaac, H.B.; Lee, C.Y.J.; Huang, S.H.H.; Teng, L.; Halliwell, B.; Wise, S.D. Lack of effect of acute oral ingestion of vitamin C on oxidative stress, arterial stiffness or blood pressure in healthy subjects. Free Radic. 2008, 42, 514-522. [CrossRef] [PubMed]

67. Rasool, A.H.; Rehman, A.; Wan Yusuf, W.N.; Rahman, A.R. Vitamin E and its effect on arterial stiffness in postmenopausal women-A randomized controlled trial. Int. J. Clin. Pharmacol. Ther. 2003, 41, 587-592. [CrossRef] [PubMed] 